\title{
Analisis Sentimen Terhadap Debat Pemilihan Gubernur Jakarta Tahun 2017
}

\author{
Rudelvi Yana Yanis \\ SMK Eklesia Jailolo \\ Halbar, Maluku Utara \\ Email:meiviyanis04@gmail.com
}

Diterima: 27 Juli 2018 | Diperbaiki: 16 Agustus 2018 | Disetujui: 20 Agustus 2018

\begin{abstract}
Abstrak -- Pemilihan Gubernur DKI Jakarta adalah salah satu simbolisasi momentum konsolidasi demokrasi di Indonesia, seluruh rakyat Jakarta harus mengenal calon kandidat yang akan menjadi pemimpinnya. Debat Cagub dan Cawagub diadakan untuk mengetahui sejauh mana integritas calon, leadership, dan kapasitas kandidat dalam menjalankan program membangun Jakarta yang lebih baik ke depannya. Pelaksanaan Debat Cagub dan Cawagub ini berdampak pada persepsi masyarakat akan kepemimpinan calon kandidat setelah menjadi Gubernur Jakarta. Sentimen negatif dan positif pun bermunculan dalam memberi penilaian terhadap tiga paslon yang mencalonkan diri sebagai Cagub dan Cawagub DKI Jakarta. Penelitian ini bertujuan untuk mengetahui topik - topik pembahasan apa saja yang mempengaruhi sentimen terkait Debat Calon Gubernur dan Wakil Gubernur DKI Jakarta. Penelitian ini menggunakan pendekatan kualitatif dan metode pengumpulan data dokumentasi dengan bantuan Perangkat Lunak Atlas. ti. Proses analisis dan klasifikasi dokumen menggunakan data dalam bentuk teks dokumen yang diambil dari media online detik.com . Data yang dikumpulkan adalah dokumen berisi tentang Debat Calon Gubernur pada tahun 2017 yang diambil dari Debat pertama pada tanggal 13 Januari 2017,Debat kedua pada tanggal 27 Januari 2017, dan Debat ketiga pada 10 Februari 2017. Berdasarkan hasil analisis dokumen pada media online detik.com terkait dengan Debat Cagub dan Cawagub DKI Jakarta tahun 2017, hasil klasifikasi menunjukkan bahwa opini terbanyak terdapat pada Debat ketiga dengan 151 opini positif dan 145 opini negatif.
\end{abstract}

Kata kunci: Analisis Sentimen, Kualitatif, Pelayanan Gubernur Jakarta 2017, Atlas.ti

\section{PENDAHULUAN}

Pemilihan umum Gubernur DKI Jakarta 2017 dilaksanakan untuk menentukan Gubernur dan Wakil Gubernur DKI Jakarta periode 2017-2022. Pemilihan Gubernur kali ini merupakan pemilihan kepala daerah ketiga bagi Jakarta yang dilakukan secara langsung menggunakan sistem pencoblosan. Komisi Pemilihan Umum Daerah (KPUD) DKI Jakarta menggelar Debat terbuka Cagub-Cawagub DKI periode 2017-2022. Debat ini adalah Debat putaran pertama yang dilaksanakan di Hotel Bidakara, Jakarta Selatan dan diselenggarakan selama 3 kali, yaitu pada tanggal 13 Januari 2017 dengan materi
Pembangunan Sosial Ekonomi untuk Jakarta, 27 Januari 2017 dengan materi Reformasi Birokrasi, Pelayanan Publik, dan Pengelolaan Kawasan Perkotaan, dan yang ketiga yaitu pada tanggal 10 Februari 2017 dengan materi tentang Kependudukan dan Peningkatan Kualitas Hidup Masyarakat Jakarta [1].

Ketua KPU DKI Jakarta Sumarno menjelaskan tujuan digelarnya Debat ini yakni mengetahui sejauh mana integritas calon, leadership, dan kapasitas kandidat dalam menjalankan program membangun Jakarta. Pilgub DKI merupakan salah satu simbolisasi momentum konsolidasi demokrasi di Indonesia, dimana seluruh rakyat Jakarta harus mengenal calon kandidat yang akan menjadi pemimpinnya [2].

Lembaga masyarakat Populi Center memprediksi ada hampir 30 persen pemilih di Pilkada DKI yang dapat dipengaruhi preferensinya melalui Debat. Direktur Populi Center Usep S Ahyar berpendapat bahwa pemilih yang masih bisa beralih atau swing voters dalam Pilkada DKI berjumlah 29\%. Jumlah itu diperoleh berdasarkan hasil survei yang dilakukan Populi Center pada 7-14 Desember 2016 dengan responden sebanyak 600 orang pemilih yang belum menentukan pilihan itu dapat dipengaruhi melalui Debat publik [3]. Debat yang dilakukan mempengaruhi sentimen masyarakat terhadap setiap paslon atau calon, pengaruh dapat diberikan jika peserta pilkada mampu menawarkan program yang rasional saat Debat dilaksanakan, sehingga masyarakat dapat menentukan pilihannya dengan tepat.

Selain menarik suara pemilih mengambang, Debat juga disebut mampu menjadi ajang peserta pilkada untuk menangkal berita-berita hoax. Selain itu, Debat dianggap mampu mengurangi sentimen negatif antar Cagub dan Cawagub. Pengamat politik dari Universitas Indonesia Cecep Hidayat mengatakan program Debat di KPUD dapat menjadi arena para calon untuk memunculkan perbedaan masing-masing secara lebih luas karena ditayangkan media Televisi. Dampak Debat bagi para kandidat juga positif karena bisa untuk mendulang dukungan suara [3].

Pada penelitian ini, dilakukan pengamatan berdasarkan lokasi dari sebuah teks berasal. Menurut Amitay et al., dengan mengetahui lokasi dari sebuah teks, masyarakat bisa tahu area mana yang sedang populer tentang suatu produk atau topik tertentu. Dengan melakukan pengamatan berita berdasarkan lokasi, masyarakat bisa mengetahui dari mana sumber dari opini 
tersebut berasal [4]. Melihat sentimen negatif dan positif dari masyarakat, sehingga perlu untuk mengetahui topik-topik pembahasan apa saja yang menjadi perhatian atau sorotan bagi masyarakat yang mempengaruhi terjadinya sentimen dan dari mana lokasi dari sebuah teks atau opini tersebut berasal.

Penelitian ini bertujuan untuk mengetahui topik-topik pembahasan apa saja yang mempengaruhi sentimen terkait Debat Calon Gubernur dan Wakil Gubernur DKI Jakarta. Proses analisis dan klasifikasi dokumen, dalam penelitian ini menggunakan data dalam bentuk teks dokumen yang diambil dari media online detik.com . Data yang dikumpulkan adalah dokumen berisi tentang Debat calon Gubernur pada tahun 2017 yang diambil dari Debat pertama pada tanggal 13 Januari 2017, Debat kedua pada tanggal 27 Januari 2017, dan Debat ketiga pada 10 Februari 2017 pada media online dengan menggunakan pendekatan kualitatif dengan bantuan perangkat lunak Atlas.ti.

\section{KAJIAN LITERATUR}

Pada penelitian yang berjudul analisa sentimen pada twitter mengenai penggunaaan transportasi umum darat dalam kota dengan metode SVM telah menerapkan teori sentimen analisis. Penelitian ini dilakukan untuk mengetahui opini-opini dari masyarakat mengenai penggunaan transportasi umum dalam kota melalui media social Twitter. Opini tersebut kemudian dimanfaatkan sebagai bahan analisa sentimen untuk mengetahui penilaian pelayanan transportasi umum darat dalam kota apakah positif atau negatif, serta mengetahui faktor opini apa yang sering muncul. Dari penelitian yang sudah dilakukan, didapat kesimpulan bahwa, analisa sentimen terhadap data twitter mengenai penggunaan transportasi umum darat dalam kota dapat dilakukan dengan metode SVM mencapai akurasi 78.12\% pada dataset Trans Jakarta. Hasil akurasi tersebut dipengaruhi oleh beberapa hal seperti komposisi jumlah data traning dan testing, jumlah dataset yang digunakan, komposisi jumlah data positif dan negatif [5].

Penelitian terdahulu yang berjudul analisis sentimen kebijakan publik terhadap ujian nasional dengan metode Nä̈ve Bayes Classifier (NBC). Penelitian ini menggunakan metode NBC dan Quintuple untuk mengklasifikasi dokumen yang terkait dengan ujian nasional. Dari hasil analisis dan klasifikasi dokumen secara keseluruhan menentukan sentimen publik dalam melaksanakan ujian nasional memiliki sentimen negatif, dengan kategori pendapat positif $32 \%$ dan pendapat negatif $68 \%$. Hasil pengolahan data dan klasifikasi dokumen berdasarkan polaritas pendapat positif dalam melaksanakan ujian nasional tahun 2012 memiliki sentimen positif lebih tinggi yaitu 44\%, dibandingkan dengan ujian nasional tahun 2013 dengan $20 \%$ sentimen positif. Sebaliknya untuk kategori pendapat negatif ujian nasional tahun 2013 memiliki sentimen negatif tertinggi yaitu $80 \%$ dibandingkan dengan ujian nasional tahun 2012 yaitu 56\%. Hasil akurasi klasifikasi dokumen untuk menentukan polarisasi opini publik terhadap pelaksanaan ujian nasional 2012 dan ujian nasional 2013 secara keseluruhan mengungkapkan bahwa akurasi klasifikasi dokumen menggunakan metode NBC memiliki tingkat akurasi yang tinggi, mencapai $93 \%$ dibandingkan dengan metode quintuple dengan akurasi $83 \%$ [6].

Penelitian terdahulu yang berjudul analisis sentimen terkait kenaikan harga BBM pada media online dengan bantuan perangkat lunak Atlas.ti. Hasil analisis dan klasifikasi dokumen, sentimen publik terkait kenaikan harga BBM pada detik.com dan kompas.com menunjukkan sentimen negatif. Hasil pengolahan data dan klasifikasi data secara keseluruhan menunjukkan opini positif $32 \%$ dan opini negatif $68 \%$.Hasil klasifikasi dokumen berdasarkan polarisasi opini publik terkait kebijakan kenaikan harga BBM menunjukan bahwa pada detik.com memiliki opini positif $35 \%$ dan negatif $65 \%$. Sementara itu, pada kompas.com memiliki opini positif $29 \%$ dan opini negatif $71 \%$ [7].

Penelitian 7 digunakan sebagai acuan dalam membangun penelitian ini. Dalam penelitian ini akan melakukan klasifikasi dokumen teks terkait pemilihan Gubernur Jakarta tahun 2017 berdasarkan sentimen dari publik pada media online.

\section{A. Analisis Sentimen}

Sentimen analysis atau opinion mining mengacu pada bidang yang luas dari pengolahan bahasa alami, komputasi linguistic dan text mining yang bertujuan menganalisa pendapat, sentimen, evaluasi, sikap, penilaian dan emosi seseorang apakah pembicara atau penulis berkenaan dengan suatu topik, produk, layanan, organisasi, individu, ataupun kegiatan tertentu [8].

Tugas dasar dalam analisis sentimen adalah mengelompokkan polaritas dari teks yang ada dalam sebuah kalimat, dokumen, fitur atau tingkat aspek kemudian menentukan pendapat yang dikemukakan dalam kalimat, dokumen, fitur atau tingkat aspek tersebut apakah bersifat positif, negatif, atau netral [9].

Ekspresi atau sentimen mengacu pada fokus topik tertentu, pernyataan pada suatu topik mungkin akan berbeda makna dengan pernyataan yang sama pada subject yang berbeda. Oleh karena itu, pada beberapa penelitian terutama pada review produk, pekerjaan didahului dengan menentukan elemen dari sebuah produk yang sedang dibicarakan sebelum memulai proses opinion mining [10].

Liu mengidentifikasikan bahwa kalimat opini adalah kalimat yang mengungkapkan pendapat positif atau negatif secara eksplisit maupun implisit. Liu juga mengatakan bahwa kalimat opini bisa dalam bentuk kalimat subjektif atau kalimat objektif. Pendapat eksplisit adalah pendapat yang diungkapkan secara eksplisit terhadap fitur atau objek dalam kalimat subjektif. Sementara itu, pendapat implicit merupakan pendapat tentang fitur atau objek yang tersirat dalam kalimat obdijektif [11]

\section{Atlas.ti}

Atlas.ti adalah sebuah tool penting yang memfasilitasi para peneliti untuk menganalisis data secara terorganisir dengan baik, sistematis, efektif dan efisien untuk analisis data dalam banyak studi kasus[12][13][14][15][16]. Perangkat lunak ini membuat data kualitatif lebih visual, portable dan juga memudahkan proses analisis. Atlas.ti tidak hanya alat yang untuk mendukung analisis data kualitatif dan juga sebagai pemdamping sampai akhir project. Misalnya mereka dapat membuat memo gratis, yang fokus pada refleksivitas terkait dengan pengaturan dari proses penelitian. Refleksivitas pada dasarnya berarti membuat refleksi dan akuntansi, bagaimana keputusan di buat dan dipengaruhi dalam proses penelitian. Misalnya, peneliti dapat mencerminkan dan dicatat dalam memo, mengapa teori X lebih disukai daripada teori Y untuk membingkai penelitian. Refleksivitas dilakukan melalui memo prosedural, di mana para peneliti mulai menggambarkan fenomena yang akan diteliti, latar belakang masalah atau masalah yang akan diteliti dan sebagainya. Refleksivitas tidak dibatasi hanya untuk analisis data, melainkan perlu dilakukan selama proses penelitian seluruh [17]. 
Tool Atlas.ti membantu peneliti menganalisis secara sistematis fenomena data yang kompleks baik itu berupa teks dan multimedia. Atlas.ti juga mempunyai fitur tambahan untuk pengembangan teori seperti kemampuan untuk membangun sebuah diagram konseptual yang menunjukkan relevansi antara ide [18].

\section{METODE PENELITIAN}

Penelitian ini menggunakan metodologi seperti dijelaskan pada Gambar 1 berikut :

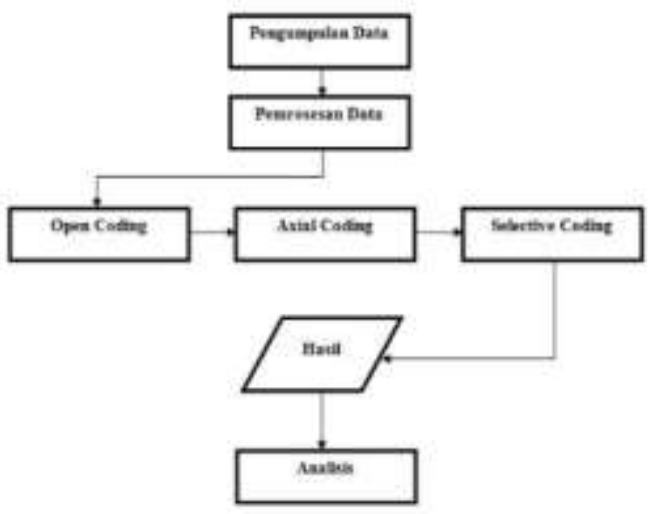

\section{A. Pengumpulan Data}

Pengumpulan data yang dilakukan pada penelitian ini dilakukan secara manual yaitu dengan menggunakan teknik penelusuran Internet. Pengumpulan data dalam penelitian ini menggunakan metode Dokumentasi yang diambil dari media online, yakni : http://www.detik.com [19]. Data yang digunakan adalah dalam bentuk dokumen teks berita dari media online (detik.com). Data yang digunakan yaitu data dari hasil pengelompokkan polaritas dari teks yang ada dalam dokumen, kalimat atau fitur entitas apakah pendapat yang dikemukakan dalam dokumen atau kalimat memiliki aspek atau ekspresi atau sentimen. Sebagai contoh : menurut herry Masyarakat kami butuh Gubernur yg bekerja keras untuk rakyat : $100 \%$ transparent dalam APBD, $100 \%$ transparent berani memberantas Korupsi, $100 \%$ hati dan jiwa yg penuh kasih bekerja dengan tulus untuk kemajuan masyarakat DKI Jakarta. Entitas atau objek adalah tentang kepemimpinan yang transparan, aspeknya adalah birokrasi, pendapat atau sentimennya adalah positif, karena kepemimpinan yang transparan berdampak pada birokrasi politik daerah.

Data yang dikumpulkan berupa 200 teks berita atau artikel terkait dengan Debat Calon Gubernur dan Wakil Gubernur Jakarta. Untuk periode waktu pengumpulan data pada detik.com berdasarkan tanggal Debat yang ditentukan oleh Kpu yaitu 13 Januari 2017, 27 Januari 2017, dan terakhir pada 10 Februari 2017.

\section{B. Pemrosesan Data}

Dokumen teks berita yang telah dikumpulkan kemudian dilakukan pemrosesan data menggunakan pendekatan kualitatif dengan proses penyandian (Coding) dengan bantuan perangkat lunak Atlas.ti. Terdapat tiga teknik penyandian antara lain open coding, axial coding dan selective coding.

\section{1) Open Coding (penyandian terbuka)}

Proses open coding (penyandian terbuka) adalah proses identifikasi konsep, dimana fitur dan dimensi mereka ditemukan dalam data [20][21]. Selama proses penyandian terbuka, data dipecah menjadi bagian-bagian diskrit, diteliti dengan seksama dan dibandingkan untuk kesamaan atau 130 perbedaan. Peristiwa, kejadian, tindakan, benda dan interaksi yang ditemukan sama atau terkait secara konseptual dikelompokkan dalam konsep yang lebih abstrak yang disebut kategori. Proses dalam penyandian terbuka dapat dilihat pada Tabel 1.

Tabel 1. Contoh Awal Penyandian Terbuka

\begin{tabular}{|c|c|}
\hline Kotivan Permataas & Saadi \\
\hline 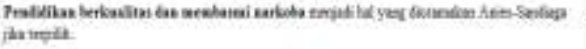 & Pessthas Britalery \\
\hline 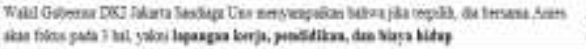 & 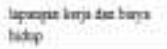 \\
\hline 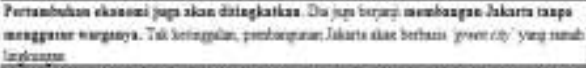 & 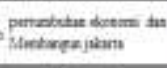 \\
\hline 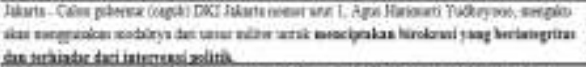 & 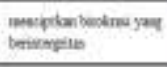 \\
\hline 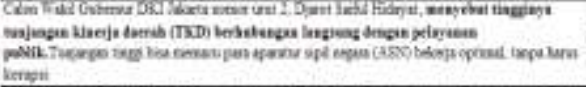 & 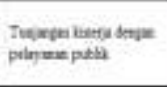 \\
\hline 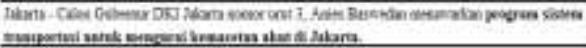 & 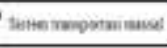 \\
\hline 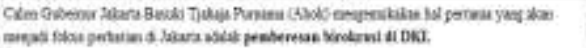 & mersax \\
\hline 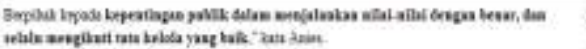 & byestopeptas \\
\hline
\end{tabular}

Hasil Open coding seperti ditunjukkan dalam Tabel 1 menghasilkan 168 sandi. Untuk mengurangi jumlah sandi yang dihasilkan, proses selanjutnya adalah mengelompokkan sandi sandi ke dalam kelompok atau kategori yang lebih umum. Suatu sandi diberikan kepada suatu kejadian, aksi atau obyek dimengerti sebagai indikator-indikator dari suatu fenomena tertentu [20].

2) Axial Coding (penyandian aksial)

Pada tahap axial coding (penyandian aksial) adalah proses yang merelasikan kategori-kategori kepada sub-kategori yang disebut 'aksial' karena penyandian terjadi disekitar suatu kategori sebagai sumbu, dan demikian menghubungkan kategori pada tingkat sifat dan dimensi [20][21]. Tujuan dari penyandian aksial untuk mengumpulkan kembali data yang telah dipenggal-penggal selama penyandian terbuka. Proses pengelompokkan sandi-sandi ke dalam kategori yang lebih umum berdasarkan teori-teori yang mendukung ke dalam kategori tersebut. Contoh Proses Axial Coding dapat dilihat pada Tabel 2.

Tabel 2. Contoh Pengelompokkan Menjadi Kategori

\begin{tabular}{ll}
\hline \multicolumn{1}{c}{ Sandi } & \multicolumn{1}{c}{ Kategori } \\
\hline Pendidikan berkualitas & $\begin{array}{l}\text { Pelayanan publik dan Anti } \\
\text { Narkotika }\end{array}$ \\
\hline $\begin{array}{l}\text { Lapangan Kerja dan Biaya } \\
\text { hidup }\end{array}$ & Lapangan pekerjaan \\
\hline Pertumbuhan ekonomi & Sosial ekonomi \\
\hline $\begin{array}{l}\text { Menciptkan birokrasi yang } \\
\text { berintegritas }\end{array}$ & Keadilan social \\
\hline $\begin{array}{l}\text { Tunjangan Kinerja dengan } \\
\text { Pelayanan Publik }\end{array}$ & Pelayanan publik \\
\hline Sistem transportasi massal & Tranportasi \\
\hline $\begin{array}{l}\text { Meningkatkan kualitas } \\
\text { lingkungan hidup }\end{array}$ & Lingkungan \\
\hline Kepentingan politik & Reformasi birokrasi \\
\hline
\end{tabular}

Contoh hasil penyandian aksial pada Tabel 2.memperlihatkan pengelompokkan sandi-sandi tersebut ke dalam kategori yang lebih tinggi. 


\section{3) Selective Coding (penyandian selektif)}

Pada tahap akhir selective coding (penyandian selektif) adalah kategori-kategori yang didapat selama penyandian terbuka dan penyandian aksial secara sistematis diintegrasi untuk membentuk skema yang lebih besar, yang merupakan suatu katerori utama. Prosedur penyandian selektif sangat mirip dengan penyandian aksial, kecuali untuk tingkat agregasi dimana penyandian aksial kategori-kategori dihubungkan kepada sub-kategori mereka, sedangkan dalam penyandian selektif terjadi integrasi antara kategori inti dengan kategorikategori untuk mencari makna dari setiap kategori [22]. Contoh proses penyandian selektif dapat dilihat pada Gambar 2.

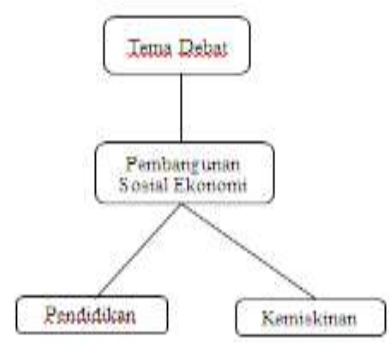

Gambar 2. Proses Penyandian Selektif

Gambar 2 menunjukkan proses untuk mengidentifikasi kategori utama, atau kategori yang menjadi tema sentral dalam penelitian. Dalam hal ini yaitu mencari makna dari setiap kategori-kategori yang telah diintegrasikan untuk mencari sentimen positif dan sentimen negatif dari setiap kategorikategori.

\section{HASIL DAN PEMBAHASAN}

Hasil penelitian yang telah dilakukan dengan menggunakan tiga teknik penyandian (coding) yaitu Open Coding, Axial Coding, dan Selective Coding dengan bantuan perangkat lunak Atlas.ti, secara keseluruhan dapat ditunjukkan pada Gambar 3.

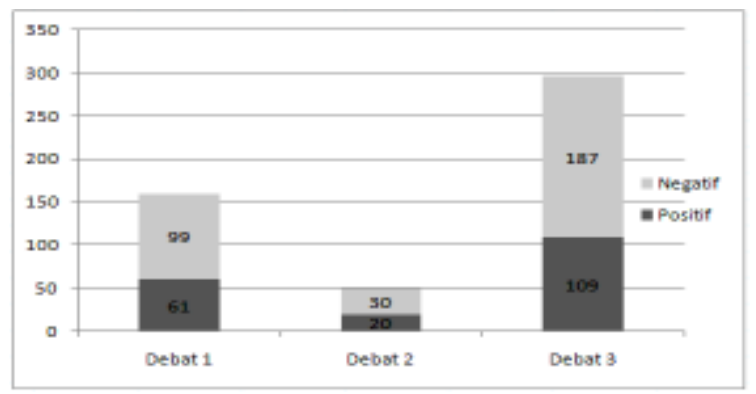

Gambar 3. Visualisasi Sentimen Pada Dokumen

Terkait dengan Debat Cagub dan Cawagub Jakarta 2017 pada Detik.com

Gambar 3 merupakan hasil klasifikasi artikel atau dokumen pada media online detik.com terkait dengan Debat Cagub dan Cawagub DKI Jakarta tahun 2017. Hasil klasifikasi pada artikel atau dokumen menunjukkan bahwa opini terbanyak pada Debat ketiga dengan 187 opini positif dan 109 opini negatif.

Hasil klasifikasi dokumen mengenai topik pembahasan terkait dengan Debat Cagub dan Cawagub DKI Jakarta 2017dapat dilihat pada Tabel 3.
Tabel 3. Opini Debat Cagub dan Cawagub DKI Jakarta 2017 pada Detik.com

\begin{tabular}{lccc}
\hline \multicolumn{1}{c}{ Topik Pembahasan } & \multicolumn{3}{c}{ Opini } \\
\cline { 2 - 4 } & Paslon 1 & Paslon 2 & Paslon 3 \\
\hline $\begin{array}{l}\text { Pembangunan Sosial Ekonomi } \\
\text { untuk Jakarta }\end{array}$ & 10 & 45 & 105 \\
\hline $\begin{array}{l}\text { Reformasi birokrasi dan } \\
\text { pelayanan publik }\end{array}$ & 8 & 30 & 12 \\
\hline $\begin{array}{l}\text { Kependudukan dan } \\
\text { Peningkatan Kualitas Hidup } \\
\text { Masyarakat Jakarta. }\end{array}$ & 20 & 142 & 134 \\
\hline
\end{tabular}

Data pada Tabel 3 dapat dijelaskan bahwa topik terhangat dan menjadi sorotan bagi masyarakat Jakarta terkait dengan Debat Cagub dan Cawagub 2017 yaitu Pembangunan Sosial Ekonomi untuk Jakarta, Reformasi birokrasi dan pelayana Publik, Kependudukan dan peningkatan Kualitas hidup masyarakat Jakarta. Ketiga topik ini terekam melalui tiga proses penyandian. Ketiga topik ini dapat dijelaskan berdasarkan teoriteori yang mendukung ketiga topik tersebut.

Edi Suharto mengartikan Pembangunan Sosial sebagai pendekatan pembangunan yang bertujuan meningkatkan kualitas kehidupan manusia secara paripurna, yakni memenuhi kebutuhan manusia yang terentang mulai dari kebutuhan fisik sampai social [23]. Pada Debat yang dilaksanakan dengan topik Pembangunan Sosial Ekonomi untuk Jakarta telah menjadi topik paling banyak dibicarakan yaitu pada paslon 3 dengan jumlah opini sebanyak 105 opini.

Reformasi birokrasi merupakan upaya pemerintah untuk meningkatkan kinerja melalui berbagai cara dengan tujuan efektifitas, efisien, dan akuntabilitas. Dimana reformasi biokrasi itu mencakup beberapa perubahan seperti, memiliki pola pikir yang sadar bahwa birokrasi sebagai pelayan masyarakat harus memiliki sikap dan pola tindak yang baik sesuai dengan peraturan perundang-undangan dalam artian tidak menyimpang dari peraturan yang telah ditetapkan. Birokrasi harus selalu mengutamakan hasil akhir dari pelayanan yang mereka berikan kepada masyarakat seperti menciptakan kepuasan pada masyarakat dan merubah manajemen kinerja birokrasi agar dapat menjadi lebih efektifdibandingkan sebelumnya [24]. Berdasarkan hasil klasifikasi dokumen mengenai topik pembahasan terkait dengan Debat Cagub dan Cawagub DKI Jakarta 2017 pada tabel 3 di atas dengan topik reformasi birokrasi dan pelayanan publik, jumlah opini terbanyak terdapat pada pada paslon dengan no urut 2, berjumlah 30 opini masyarakat.

Kualitas hidup berkaitan dengan pencapaian kehidupan manusia yang ideal atau sesuai dengan yang diinginkan. Hornuist mengartikan kualitas hidup sebagai tingkat kepuasan hidup individu pada area fisik, psikologis, sosial, aktivitas, materi, dan kebutuhan struktural. Mengemukakan defenisi kualitas hidup sebagai derajat kepuasan atas penerimaan suasana kehidupan saat ini. Calman memberikan satu definisi dari kualitas hidup yang dapat diterima secara umum, yakni perasaan subjektif seseorang mengenai kesejahteraan dirinya, berdasarkan pengalaman hidupnya saat ini secara keseluruhan [25]. Berdasarkan pengertian menurut para ahli tersebut dapat disimpulkan bahwa kualitas hidup merupakan perasaan subjektif seseorang mengenai kesejahteraan dirinya, berdasarkan pengalaman hidupnya saat ini secara keseluruhan. Kualitas hidup menggambarkan pencapaian kehidupan manusia yang ideal atau sesuai denganyang diinginkan.

Kualitas hidup yang baik dapat ditinjau dari kehidupan ekonomi, tingkat kesehatan, dan tingkat pendidikan. Tingkat 
pertambahan penduduk juga akan sangat berpengaruh terhadap kualitas hidup di wilayah tersebut. Dalam bidang ekonomi, yang sangat berkaitan dengan pekerjaan dan pendapatan, jika jumlah penduduk dalam suatu wilayah tinggi, maka persaingan mendapatkan pekerjaan pun akan semakin ketat, dan peluang kerja pun semakin sedikit. Pembangunan kependudukan dan masyarakat berkualitas merupakan bagian yang penting dalam pembangunan yang berkelanjutan, baik untuk mengendalikan kuantitas penduduk maupun untuk meningkatkan kualitas insani dan sumberdaya manusia.

Dari hasil analisis pada Tabel 3, yang terekam melalui tiga proses penyandian dapat memperlihatkan pengelompokkan sandi-sandi ke dalam kelompok atau kategori yang lebih umum kemudian mengidentifikasi kategori utama, atau kategori yang menjadi sentral dalam penelitian. Hasil pengelompokkan dapat dilihat pada Tabel 4 .

Tabel 4. Topik-Topik Pembahasan Debat Cagub dan Cawagub DKI Jakarta 2017

\begin{tabular}{|c|c|c|}
\hline Kategori Utama & Kategori & Sandi \\
\hline \multirow{5}{*}{$\begin{array}{l}\text { Pembangunan Sosial } \\
\text { Ekonomi vntvk Jakarta }\end{array}$} & Lapangan Pekerjaan & -mengurangi pengangguran \\
\hline & Kemiskinan & - program bantuan langsung \\
\hline & Transportasi Tata Kota & -kemacetan \\
\hline & linghungan & - pembangunan berbasis Green city \\
\hline & Pendidikan & - Jaminan sekolah sampai kuliah \\
\hline \multirow{4}{*}{$\begin{array}{l}\text { Reformasi birokrasi dan } \\
\text { pelayanan publik }\end{array}$} & Pelayanan publik & -KJP tepat sasaran \\
\hline & Tranportasi & - Traportasi massal \\
\hline & UMKM atau dunia usaha & - Dana bergulir \\
\hline & Tempat tinggal & - Program Rumah untuk Warga \\
\hline \multirow{4}{*}{$\begin{array}{l}\text { Kependudukan dan } \\
\text { Peningkatan Kualitas Hidúp } \\
\text { Masyarakat Jakarta. }\end{array}$} & pemberdayaan perempuan & -Menggerakan PKK lewat perempuan \\
\hline & perlindúngan anak & $\begin{array}{l}\text { - CCTV diberbagai tempat bermain untuk } \\
\text { anak-anak }\end{array}$ \\
\hline & Anti Narkotika & -BimbinganKonseling di Puskesmas \\
\hline & kebijakan untuk disabilitas. & - Memberdayakandisabilitas \\
\hline
\end{tabular}

Tabel 4 merupakan Contoh hasil pengelompokkan topik- topik pembahasan tentang Debat Cagub dan Cawagub DKI Jakarta 2017. Terdapat tiga topik terhangat pada kategori utama yang menjadi sorotan bagi masyarakat terkait dengan Debat Cagub dan Cawagub. Pada penelitian ini, peneliti akan memberikan informasi mengenai tiga topik positif dan tiga topik negatif yang menjadi sorotan bagi masyarakat yang mempengaruhi terjadinya sentimen terhadap Debat Cagub dan Cawagub DKI Jakarta 2017. Melalui informasi ini kita dapat mengetahui topik apa saja yang menjadi sorotan bagi masyarakat terhadap media online yaitu detik.com dari dua sisi positif dan negatif yang dapat di tunjukkan pada Tabel 5.

Tabel 5. Opini masyarakat terhadap Debat Pertama Cagub dan Cawagub DKI Jakarta 2017 Pada Detik.com

\begin{tabular}{lcccccc}
\hline \multirow{2}{*}{ Topik } & \multicolumn{5}{c}{ Opini } \\
\cline { 2 - 6 } Pembahasan & \multicolumn{2}{c}{ Paslon 1 } & \multicolumn{2}{c}{ Paslon 2 } & \multicolumn{2}{c}{ Paslon 3 } \\
\cline { 2 - 7 } & Positif & Negatif & Positif & Negatif & Positif & Negatif \\
\hline $\begin{array}{l}\text { Pembangunan } \\
\text { Sosial }\end{array}$ & 6 & 4 & 30 & 15 & 25 & 80 \\
$\begin{array}{l}\text { Ekonomi } \\
\text { untuk Jakarta }\end{array}$ & & & & & & \\
\hline
\end{tabular}

Hasil analisis pada Tabel 5 dapat dijelaskan bahwa topik-topik yang menjadi sorotan bagi masyarakat terkait dengan Debat pertama Cagub dan Cawagub DKI Jakarta terhadap media online yang memiliki kategori tertinggi yaitu pada Paslon nomor urut tiga dimana dengan 25 opini positif dan 80 opini negatif.

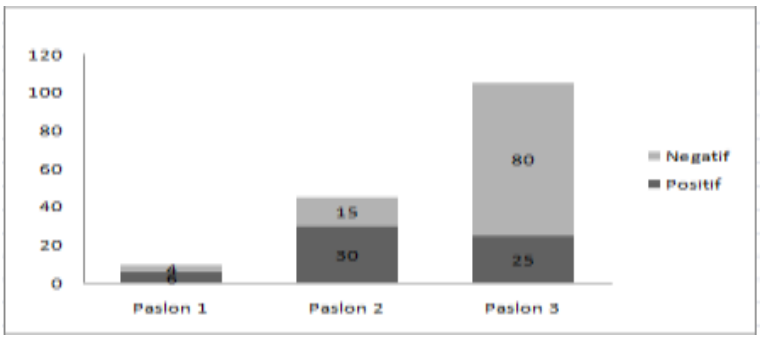

Gambar 4. Visualisasi Sentimen Secara Keseluruhan Pada Debat pertama

Gambar 4 menunjukkan hasil pengolahan data dan klasifikasi dokumen, terkait Debat Cagub dan CawagubDKI Jakarta tahun 2017 padaDetik.com . Secara keseluruhan yaitu pada Paslon tiga memiliki 25 opini positif dan 80 opini negatif berdasarkan topik pembahasan pada Debat Pertama Cagub dan Cawagub DKI Jakarta 2017.

Tabel 6. Opini masyarakat terhadap Debat kedua Cagub dan Cawagub DKI Jakarta 2017 Pada Detik.com

\begin{tabular}{lcccccc}
\hline \multirow{2}{*}{ Topik Pembahasan } & \multicolumn{6}{c}{ Opini } \\
\cline { 2 - 7 } & $\begin{array}{c}\text { Paslon 1 } \\
\text { tif }\end{array}$ & $\begin{array}{c}\text { Ne- } \\
\text { gatif }\end{array}$ & $\begin{array}{c}\text { Posi- } \\
\text { tif }\end{array}$ & $\begin{array}{c}\text { Ne- } \\
\text { gatif }\end{array}$ & $\begin{array}{c}\text { Posi- } \\
\text { tif }\end{array}$ & $\begin{array}{c}\text { Ne- } \\
\text { gatif }\end{array}$ \\
\hline $\begin{array}{l}\text { Reformasi birokrasi } \\
\text { dan pelayanan publik }\end{array}$ & 6 & 2 & 25 & 5 & 9 & 3 \\
\hline
\end{tabular}

Hasil analisis pada Tabel 6, dapat dijelaskan bahwa topik-topik yang menjadi sorotan bagi masyarakat terkait dengan Debat kedua Cagub dan Cawagub DKI Jakarta terhadap media online yang memiliki kategori tertinggi yaitu pada Paslon Nomor urut dua dimana dengan 25 opini positif dan 5 opini negatif.

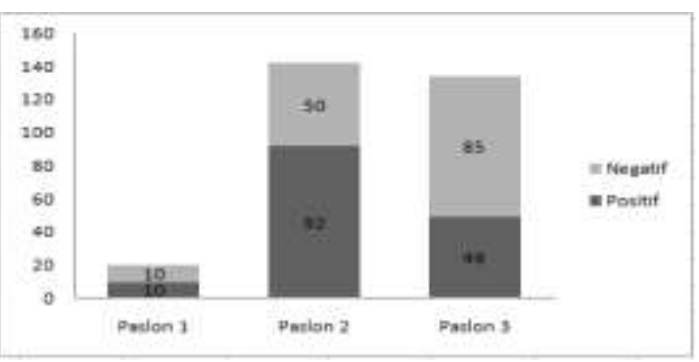

Gambar 5. Visualisasi Sentimen Secara Keseluruhan Pada Debat kedua

Gambar 5 menunjukkan hasil pengolahan data dan klasifikasi dokumen, terkait Debat Cagub dan CawagubDKI Jakarta tahun 2017 pada Detik.com . Secara keseluruhan yaitu pada Paslon dua memiliki 25 opini positif dan 5 opini negatif berdasarkan topik pembahasan pada Debat kedua Cagub dan Cawagub DKI Jakarta 2017.

Tabel 7. Opini masyarakat terhadap Debat ketiga Cagub dan Cawagub DKI Jakarta 2017 Pada Detik.com

\begin{tabular}{|c|c|c|c|c|c|c|}
\hline \multirow{3}{*}{$\begin{array}{c}\text { Topik } \\
\text { Pembahasan }\end{array}$} & \multicolumn{6}{|c|}{ Opini } \\
\hline & \multicolumn{2}{|c|}{ Paslon 1} & \multicolumn{2}{|c|}{ Paslon 2} & \multicolumn{2}{|c|}{ Paslon 3} \\
\hline & $\begin{array}{l}\text { Posit } \\
\text { if }\end{array}$ & $\begin{array}{c}\text { Negat } \\
\text { if }\end{array}$ & $\begin{array}{l}\text { Posit } \\
\text { if }\end{array}$ & $\begin{array}{l}\text { Negat } \\
\text { if }\end{array}$ & $\begin{array}{c}\text { Posit } \\
\text { if }\end{array}$ & $\begin{array}{c}\text { Negat } \\
\text { if }\end{array}$ \\
\hline $\begin{array}{l}\text { Kependudukan dan } \\
\text { Peningkatan } \\
\text { Kualitas Hidup } \\
\text { Masyarakat Jakarta }\end{array}$ & 10 & 10 & 92 & 50 & 49 & 85 \\
\hline
\end{tabular}


Hasil analisis pada Tabel 7 dapat dijelaskan bahwa topik-topik yang menjadi sorotan bagi masyarakat terkait dengan Debat kedua Cagub dan Cawagub DKI Jakarta terhadap media online yang memiliki kategori tertinggi yaitu pada Paslon No dua dimana dengan 92 opini positif dan 50 opini negatif.

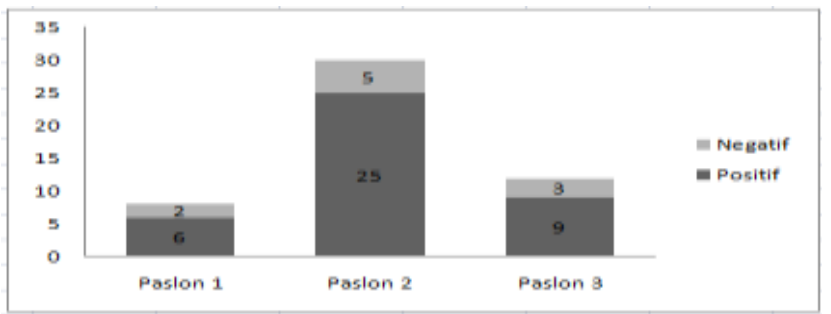

Gambar 6. Visualisasi Sentimen Secara Keseluruhan Pada Debat kedua

Gambar 6 menunjukkan hasil pengolahan data dan klasifikasi dokumen, terkait Debat Cagub dan Cawagub DKI Jakarta tahun 2017 pada Detik.com. Secara keseluruhan yaitu pada Paslon dua memiliki 92 opini positif dan 50 opini negatif berdasarkan topik pembahasan pada Debat kedua Cagub dan Cawagub DKI Jakarta 2017

Tabel 7. Jumlah Opini Negatif dan Positf dari Keseluruhan debat pada Paslon 1, Paslon 2 dan Paslon 3

\begin{tabular}{|c|c|c|c|c|c|c|}
\hline \multirow{2}{*}{ Topik Pembasan } & \multicolumn{6}{|c|}{ Opini } \\
\cline { 2 - 7 } & \multicolumn{2}{|c|}{ Paslon 1 } & \multicolumn{2}{c|}{ Paslon 2 } & \multicolumn{2}{c|}{ Paslon 3 } \\
\cline { 2 - 7 } & $\begin{array}{c}\text { Posit } \\
\text { if }\end{array}$ & $\begin{array}{c}\text { Negat } \\
\text { if }\end{array}$ & $\begin{array}{c}\text { Posit } \\
\text { if }\end{array}$ & $\begin{array}{c}\text { Negat } \\
\text { if }\end{array}$ & $\begin{array}{c}\text { Posit } \\
\text { if }\end{array}$ & $\begin{array}{c}\text { Negat } \\
\text { if }\end{array}$ \\
\hline $\begin{array}{c}\text { Pembangunan Sosial } \\
\text { Ekonomi untuk Jakarta }\end{array}$ & 6 & 4 & 30 & 15 & 25 & 80 \\
\hline $\begin{array}{c}\text { Reformasi Birokrasi dan } \\
\text { Pelayana Publik }\end{array}$ & 6 & 2 & 25 & 5 & 9 & 3 \\
\hline $\begin{array}{c}\text { Kependudukan dan } \\
\text { Peningkatan Kualitas } \\
\text { Hidup }\end{array}$ & 10 & 10 & 92 & 50 & 49 & 25 \\
\hline Jumlah opini debat & $\mathbf{2 2}$ & $\mathbf{1 6}$ & $\mathbf{1 4 7}$ & $\mathbf{7 0}$ & $\mathbf{8 3}$ & $\mathbf{1 6 8}$ \\
\hline
\end{tabular}

Hasil analisis pada Tabel 7 dapat dijelaskan bahwa topik-topik yang menjadi sorotan bagi masyarakat terkait dengan keseluruhan Debat terhadap Cagub dan Cawagub DKI Jakarta terhadap media online yang memiliki kategori tertinggi yaitu pada Paslon nomor urut tiga dimana dengan opini 83 positif dan 168 opini negatif.

\section{KESIMPULAN}

Berdasarkan hasil analisis dan pembahasan yang sudah dibuat, bisa disimpulkan bahwa opini terbanyak terdapat pada Debat ketiga dengan 187 opini positif dan 109 opini Negatif, hasil tersebut di dapatkan berdasarkan klasifikasi pada artikel atau dokumen media online Detik.com. Topik yang dibahas pada Debat ketiga adalah mengenai Kependudukan dan peningkatan Kualitas hidup masyarakat Jakarta dimana terdapat 20 opini untuk Paslon 1, 142 opini untuk Paslon 2, dan 134 opini untuk Paslon 3.

Pada Debat pertama dengan topik Pembangunan Sosial Ekonomi untuk Jakarta mendapatkan 99 opini negatif dan 61 opini positif, dimana terdapat 10 opini untuk paslon 1, pada paslon 2 terdapat 45 opini, dan 105 opini untuk paslon dengan nomor urut 3. Pada Debat kedua degan topik reformasi birokrasi dan pelayanan publik mendapatkan 30 opini negatif dan 20 opini positif, dimana terdapat 8 opini untuk paslon 1, 30 opini untuk paslon 2, dan 12 opini untuk paslon 3 .
Peningkatan kualitas hidup dan kependudukan merupakan topik yang banyak mendapat sorotan masyarakat. Topik ini membahas tentang kebijakan untuk disabilitas, anti narkotika, perlindungan anak, dan pemberdayaan perempuan. Paslon dengan nomor urut tiga mendapatkan opini terbanyak yaitu 134 opini dengan pembahasan program untuk Jakarta kedepannya yaitu pendidikan terhadap masalah narkoba, tegas terhadap distributor pengedar narkoba, menciptakan rumah belajar, memberdayakan perempuan, dan program perempuan wirausaha.

\section{REFERENSI}

[1] Nursita Sari, 2016, Jadwal Cagub dan Cawagub DKI, Kompas, Diakses 13 Januari 2017, <http://megapolitan.kompas.com>

[2] Bayu Septianto, 2017, Ketua KPU DKI Jakarta Ulas Tiga Tujuan Diadakannya Debat, Okezone News, Diakses 13 Januari 2017, <https://news.okezone.com>

[3] Basuki Rahmat, 2017, Menggerek Elektabilitas Calon Pemimpin DKI Melalui Debat, Diakses 13 Januari 2017, <https://www.cnnindonesia.com/kursipanasDKI1/201701 13101639-521-186042/mengerek-elektabilitas-calonpemimpin-DKI-melalui-debat/>

4] Amitay, E., Har'El, N., Sivan, R., dan Soffer, A., 2004, Web-a-Where: Geotagging Web Content, Proceedings of SIGIR '04 Conference on Research and Development in Information Retrieval, 273-280.

5] Novantirani, Anita, Sabariah, Mira Kania, dan Effendy, Veronikha. 2015. Analisis Sentimen pada ITwitter untuk Mengenai Penggunaan Transportasi Umum Darat Dalam Kota dengan Metode Support Vector Machine. Universitas Telkom : Bandung.

6] Rupilele F,G,.Manongga, D and Utomo, W, H. 2013. Sentiment Analysis Of National Exam Public Policy With Naive Bayes Classifier Method (NBC), Journal of Theoretical and Applied Information Technology, Vol 58 No. 1, ISSN 1992-8645.

[7] Sandy, B, C,. Manongga, D and Iriani, A. 2015. analisis sentimen terhadap kenaikan harga BBM pada media online. Makalah Disajikan Dalam Seminar Nasional Dan Konterensi Sistem Informasi, Informatika Dan Komunikasi, STIKOM Uyelindo Kupang, 28 November

[8] liu Bing, 2012, Sentimen Analysis and Opinion Mining, Chicago: Morgan and Clyapool Publisher, Diakses tanggal 29 Mei 2018, <http://www.dcc.ufrj.br/ valeriab/DTMSentimenAnaysi>

[9] Dehaff, M. 2010, Sentiment Analysis, Hard But Worth It, Diakses: $\quad$ tanggal 29 April 2018. <http://www.customerthink.com/blog/sentiment_analysis _hard_but_worth_it. Diakses : 22 Januari 2015>

[10] Berry, M.W. and Kogan, J. 2010. Text Mining Aplication and theory. WILEY : United Kingdom

[11]Liu, B. 2010. Sentiment Analysis and Subjectivity, in Handbook of Natural Language Processing, 2nd Edition. Chapman \& Hall / CRC Press

[12] Lewis, B. 2004. NVivo 2.0 and ATLAS.ti 5.0: A comparative review of two popular qualitative dataanalysis programs. Field Methods, 16(4), 439-469

[13] Lu, C.-J., and Shulman, S. W. 2008. Rigor and flexibility in computer-based qualitative research: Introducing the 
coding analysis toolkit. International Journal of Multiple Research Approaches, 2(1), 105-117.

[14] Konopásek, Z. 2008. Making thinking visible with Atlas.ti: Computer assisted qualitative analysis as textual practices [62 paragraphs]. Forum Qualitative Sozialforschung / Forum: Qualitative Social Research, 9(2), Art. 12, < http://nbnresolving.de/urn:nbn:de:0114fqs0802124>

[15] Friese, S. 2012. Qualitative data analysis with ATLAS.ti. London: SAGE Publications Ltd.

[16] Rambaree, K. and Faxelid, E. 2013 Considering Abductive Thematic Network Analysis with ATLAS.ti 6.2. In N. Sappleton (Ed.). Advancing Research Methods with New Media Technologies p. 170-186). Hershey PA, USA: IGI Global

[17] Mauthner, N. S., and Doucet, A. 2003. Reflexive accounts and accounts of reflexivity in qualitative data analysis. Sociology, 37 (3), 413-431

[18] Silverman, D. 2000. Doing Qualitative Research : A Practical Handbook. London, Thousand Oaks, New Delhi: Sage.

[19] Herdiansyah, haris. 2012. Metodologi Penelitian Kualitatif. Jakarta: Salemba Humanika

[20]Strauss, A. L. (1990). Basics of qualitative research. Grounded theory procedures and techniques. USA: Sage Publications.

[21] Strauss, A. L. \& Corbin, J (1997). Grounded theory in Practice. Thousand Oaks:Sage. Thousand Oaks: Sage.

[22] Goulding, C. 2002. Grounded Theory: A Pactical Guide for Management, Business and Market Researchers (London: Sage Publications), hal. 74-96

[23] Suharto, Edi. 2010. Analisis Kebijakan Publik. Bandung: Alfabeta.

[24] Sedarmayanti. 2009. Sumber Daya Manusia dan Produktivitas Kerja. Bandung: CVMandar Maju

[25] O'Connor. R (1993). Issue in the Meansurement of Health Quality of Live. Center For Health Program Evaluasi., Retrieved from: <http:// www. Rodococonorassoc.Com/issue_in_meansurement_of_qua . Html> 